\title{
The role of product quality, promotion, conformity in increasing consumer loyalty
}

\section{Sukaris}

Management Study Program, Faculty of Economics and Business

Universitas Muhammadiyah Gresik, East Java, Indonesia, sukaris21@umg.ac.id

\author{
Novita Tri Yulia \\ Management Study Program Faculty of Economics and Business \\ Universitas Muhammadiyah Gresik, East Java, Indonesia, \\ novitatriyulia87@gmail.com
}

\begin{abstract}
ABSTRAK
Saat ini persaingan bisnis semakin kompetitit. Perusahaan harus bertindak meningkatkan dan tetap menjaga kualitas produk. Kualitas produk merupakan kemampuan dari suatu produk dalam memenuhi kebutuhan pelanggan ataupun konsumen. Kualitas produk dapat menjadi andalan perusahaan agar produknya mampu bersaing pada segmen pasarnya dengan produk yang sejenis. Kualitas akan mendorong konsumen untuk menjalin hubungan erat dengan perusahaan dalam jangka waktu lama yang pada akhirnya tercipta loyalitas konsumen. Penelitian ini bertujuan untuk mengetahui pengaruh kualitas produk, promosi dan konformitas terhadap loyalitas konsumen pada restoran siap saji " $X$ " di Kabupaten Gresik. Sampel yang akan digunakan dalam penelitian ini adalah sebanyak 100 responden anak muda dengan menggunakan metode accidental sampling. Jenis dan sumber data yang digunakan data primer berupa data jawaban kuesioner dari responden. Pengujian dilakukan dengan menggunakan SPSS. Hasil penelitian ini menunjukkan bahwa kualitas produk, promosi dan konformitas berpengaruh positif dan signifikan terhadap loyalitas konsumen
\end{abstract}

Kata Kunci : Kualitas Produk, Promosi, Konformitas, Loyalitas

\begin{abstract}
Currently, business competition is getting more competitive. Companies must act to improve and maintain product quality. Product quality is the ability of a product to meet customer needs and consumers. Product quality can be a company's mainstay so that its products are able to compete in its market segments with similar products. Quality will encourage consumers to establish close relationships with the company for a long time which in turn creates consumer loyalty. This study aims to determine the effect of product quality, promotion and conformity on consumer loyalty at the " $X$ " fast food restaurant in Gresik Regency. The sample used in this study were 100 young respondents using the method of accidental sampling. The types and sources of data used are primary data in the form of questionnaire answers from respondents. Tests were carried out using SPSS. The results of this study indicate that product quality, promotion and conformity have a positive and significant effect on consumer loyalty.
\end{abstract}

Keywords: Product Quality, Promotion, Conformity, Loyalty.

\section{INTRODUCTION}

Consumers are one of the factors that can provide benefits for marketers. In the face of increasingly widespread brand competition, companies must act to improve and maintain product quality. Product quality is the ability of a product to meet customer needs and consumers. Product quality can be a company's mainstay so that its products are able to compete in its market segments with similar products. Quality will encourage consumers to 
forge close relationships with the company for a long period of time. After creating customer satisfaction, consumer loyalty will then be created to companies that have provided quality products that meet their needs and match their expectations.

Marketers and plans that are often used by companies are doing promotions using advertising media that are made as attractive as possible. With the aim of attracting consumers to buy the advertised product. So that consumers can feel the quality presented by the company. If consumers feel that the product they buy is of high quality and in accordance with the taste they want, then the next day the consumer will return to buy the existing product line at the company. Even though many competing brands offer similar products, the quality of the products is maintained so that the company will be able to withstand intense competition and consumers will prefer to keep buying products from that company. The importance of product quality on satisfaction and loyalty is also supported by research by Sukaris et al., (2019); Rozi, M., \& Sukaris, S. (2020) which states that quality products for consumers are products that provide value, and from the value obtained, consumers will carry out behavioral activities both purchasing, loyalty and recommendations to others.

In addition, companies are also required to provide good and memorable experiences to their customers. Because by providing a good and memorable experience to consumers, these consumers tend to share their experiences and recommend the restaurant to their friends so that consumer loyalty will be created in a relatively long period of time. Today, the majority of consumers in fast food restaurants are high school children and college students. They get together with their friends to just hang out together, do assignments together, or just spend time together. This is because they have more free time than working consumers. Based on the information obtained by the researcher, high school children and students prefer fast food restaurants " $\mathrm{X}$ ", which starts from an invitation and gets recommendations from their friends. They also said that product quality and promotion are also a consideration for consumers in choosing fast food restaurants. Then, they aligned their consumption choices to agree and follow the choices their peers had selected for fast food restaurants. Restoran fast " $\mathrm{X}$ " is the business of fast food businesses are included in the culinary field which sells various food products and beverages fast food such as hamburgers, fried chicken, french fries,soda, float, ice cream and others. The list of the most popular fast food restaurants in Indonesia in 2015-2020 is presented in table 1 below:

Table 1: Fast Food Restaurants That Are Most in Demand in Indonesia (2015-2020)

\begin{tabular}{|l|c|c|c|c|c|c|}
\hline \multicolumn{1}{|c|}{ Brand } & $\mathbf{2 0 1 5}$ & $\mathbf{2 0 1 6}$ & $\mathbf{2 0 1 7}$ & $\mathbf{2 0 1 8}$ & $\mathbf{2 0 1 9}$ & $\mathbf{2 0 2 0}$ \\
\hline KFC & $59.3 \%$ & $63.9 \%$ & $60.4 \%$ & $42.7 \%$ & $26.2 \%$ & $26.4 \%$ \\
\hline MCDonald's & $17.5 \%$ & $18.6 \%$ & $19.0 \%$ & $24.3 \%$ & $22.4 \%$ & $22.8 \%$ \\
\hline A\&W & $7.1 \%$ & $2.6 \%$ & $3.7 \%$ & $6.3 \%$ & $5.4 \%$ & $6.5 \%$ \\
\hline Hoka-Hoka Bento & $4.1 \%$ & $2.5 \%$ & $2.9 \%$ & $5.8 \%$ & $5.4 \%$ & $5.9 \%$ \\
\hline CFC & - & $2.0 \%$ & $2.7 \%$ & - & - & - \\
\hline Richeese Factory & - & - & - & $2.7 \%$ & $4.3 \%$ & $4.9 \%$ \\
\hline
\end{tabular}

Source: www.topbrand-award.com

Based on table 1 the researcher can conclude that " $\mathrm{X}$ " fast food restaurant is superior to other fast food restaurants.
Therefore, the fast food restaurant company "X" has many branches in every city. Even in East Java, especially in the City of Gresik, it 
has one branch in the city of Gresik because the fast food restaurant " $\mathrm{X}$ " always maintains and maintains the quality that has been well embedded in the minds of its consumers. So that the fast food restaurant " $\mathrm{X}$ " can be well accepted by the public and consumers become loyal to the company's products.

Based on the explanation that has been discussed on this background, the purpose of this study is to determine the effect of product quality, promotion and conformity on consumer loyalty at the " $\mathrm{X}$ " fast food restaurant.

\section{LITERATURE REVIEW}

\section{Product Quality}

According Garvin in Tjiptono (2016: 134) which states that product quality is a characteristic of a product in its ability to meet predetermined needs and has latent properties. According to Sidi (2018), stating that the more quality the product provided, the consumers will feel satisfied so that consumers will make repeat purchases in a relatively long time. So that the hypothesis proposed is:

H1: Product quality has a positive effect on consumer loyalty

\section{Promotion}

According to Kotler and Keller in Sabran (2012: 47) defines the meaning of promotion, that promotion is all forms of activity that companies carry out to communicate companyowned products to consumers and persuade consumers to buy the company's products. According to Anggia, et al (2015), stated that by carrying out promotions and giving attractive offers that are carried out regularly will make consumers more loyal to a product or brand being promoted. So the hypothesis proposed is:

H2: Promotion has a positive effect on consumer loyalty.

\section{Conformity}

According to Robert and Byrne (2005: 53), expressing his opinion that conformity is a type of social influence in which a person changes attitudes and behavior to conform to prevailing social norms. According to Nilawati, et al (2005), states that conformity is able to influence consumer attitudes and behavior to make purchases and consumption. So the hypothesis proposed is:

H3: Conformity has a positive effect on consumer loyalty

\section{Consumer loyalty}

According to Oliver, quoted by Kotler and Keller (2012: 138), expresses his opinion that loyalty is a customer who persists deeply to resubscribe or repurchase products or selected services consistently in the future, even though the influence of the situation and marketing efforts have the potential to cause behavior change.

\section{Conceptual Framework}

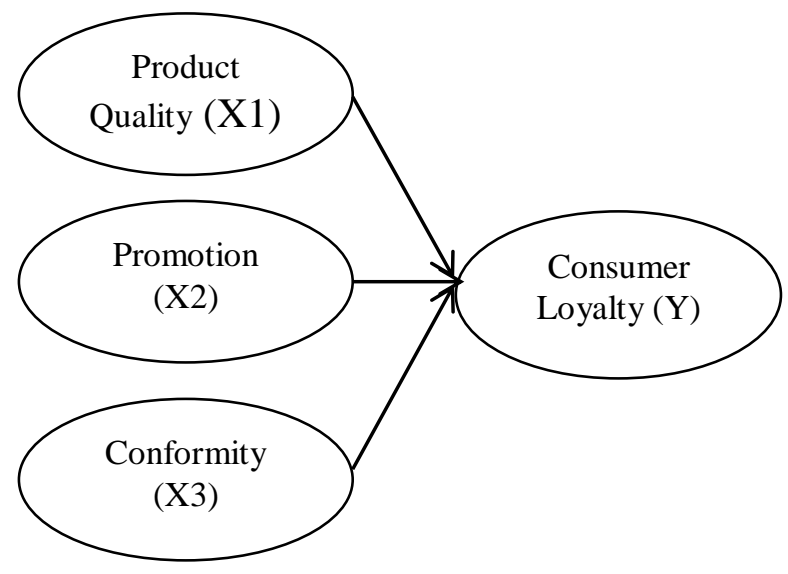

Figure 1: Conceptual Framework

\section{METHODE}

\section{Approaches}

This research uses quantitative research using associative problem formulations. As for the form of relationship using a causal relationship. This research was carried out by fast food restaurant " $\mathrm{X}$ " in Gresik Regency.

\section{Population and Sample}

The population used in this study were high school children and college students and female students. Determination of the sample 
using Ferdinand's (2002) theory, namely the number of indicators used in all latent variables multiplied by 5 to 10 . So that the respondents who were used as samples in this study were 100 respondents using the method accidental sampling.

\section{Types and Sources of Data}

The types and sources of data used by researchers in this study were primary data in the form of questionnaire answers from respondents which were respondents' statements related to product quality, promotion, conformity and consumer loyalty.

Testing Research Instruments

Table 2 Results of the Validity Test

\begin{tabular}{|c|c|c|c|}
\hline Question Items & r count & Sig & Information \\
\hline Quality of Products (X1) & & & \\
\hline X1 .1 & 0.592 & 0.000 & Valid \\
\hline X1.2 & 0.693 & 0.000 & Invalid \\
\hline X1.3 & 0.690 & 0.000 & Valid \\
\hline X1.5 & 0.567 & 0.000 & Valid \\
\hline X1.6 & 0.526 & 0.000 & Invalid \\
\hline X1.7 & 0.608 & 0,000 & Valid \\
\hline X1.8 & 0.664 & 0,000 & Valid \\
\hline Promotion (X2) & 0.735 & 0,000 & Valid \\
\hline X2.1 & & & \\
\hline X2.2 & 0.655 & 0,000 & Valid \\
\hline X2.3 & 0.761 & 0,000 & Valid \\
\hline X2.4 & 0.750 & 0.000 & Valid \\
\hline X2.5 & 0.653 & 0.000 & Invalid \\
\hline X2.6 & 0.756 & 0.000 & Valid \\
\hline Conformity (X3) & 0.729 & 0.000 & Valid \\
\hline X3.1 & & & Valid \\
\hline X3.2 & 0.634 & 0.000 & valid \\
\hline X3.3 & 0.824 & 0.000 & invalid \\
\hline X3.4 & 0.783 & 0.000 & valid \\
\hline Y.1 & 0.831 & 0.000 & valid \\
\hline Y.2 & & & valid \\
\hline Consumer Loyalty (Y) & 0.935 & 0.000 & \\
\hline
\end{tabular}

Sources: primary data are processed, 2020

Based on the output $u$ results if the validity, shows that the instruments of all independent variables and also the dependent variable are declared valid because the calculated $r$ value is greater than the $r$ table value. Meanwhile, invalid can be issued as a variable measure

\section{Data Collection Techniques and Data Analysis}

The data collection technique used by researchers is a questionnaire or questionnaire with variable measurement using a Likert scale. In this study, the questionnaire will be given to consumers who visit the fast food restaurant "X" in Gresik Regency. The data analysis technique used in this study is multiple linear regression analysis. The multiple linear regression equation model in this study is as follows:

$$
\mathrm{Y}=\beta 1 \mathrm{X} 1+\beta 2 \mathrm{X} 2+\beta 3 \mathrm{X} 3(\text { standardized })
$$

\section{RESULTS AND DISCUSSION Validity Test}


Based on the output results of testing the reliability of the above, it has been demonstrated that the indicator questionnaire on all variables both variables The independent and dependent variables used in this study are declared reliable because the value Cronbach Alpha is greater than specified, namely 0.70 .

\section{Assumption Test \\ Test Normality Test}

Table 4: Normality Test Results

\begin{tabular}{|llr|}
\hline \multicolumn{2}{|c|}{ Kolmogorov-Smirnov One-SampleTest } \\
\hline $\mathbf{N}$ & & Unstandardized Residual \\
\hline Normal Parameters & Mea & 100 \\
& Mean &, 0000000 \\
Most Extreme Differences & Std. Deviation &, 97924242 \\
& Absolute &, 073 \\
& Positive &, 054 \\
Test Statistic & Negative & -073 \\
Asymp. Sig. (2-tailed) & &, 073 \\
\hline a. Test distribution is Normal. & &, $200^{c, d}$ \\
b. Calculated from data. & \\
\hline
\end{tabular}

Source: Processed primary data, 2020

Based on the output of the normality test results above, it has shown that the Asymp value. Sig. (2-tailed) which is equal to 0.200 , where the value is greater than 0.05 , so it can be stated that the data used in this study are normally distributed.

\section{Multicollinearity Test}

Table 5: Results of Multicollinearity Test

\begin{tabular}{|c|c|c|c|c|c|c|c|}
\hline \multicolumn{8}{|c|}{ Coefficients $^{\mathrm{a}}$} \\
\hline \multirow[t]{2}{*}{ Model } & \multicolumn{2}{|c|}{$\begin{array}{c}\text { Unstandardized } \\
\text { Coefficients }\end{array}$} & \multirow{2}{*}{$\begin{array}{c}\text { Standardized } \\
\text { Coefficients } \\
\text { Beta }\end{array}$} & \multirow[t]{2}{*}{$\mathrm{T}$} & \multirow[t]{2}{*}{ Sig. } & \multicolumn{2}{|c|}{$\begin{array}{l}\text { Collinearity } \\
\text { Statistics }\end{array}$} \\
\hline & B & Std.Error & & & & Tol & VIF \\
\hline (Constant) & , 094 & 872 & & 107 &, 915 & & \\
\hline Product Quality &, 102 &, 038 & 281 & 2,717 &, 008 &, 500 & 1,998 \\
\hline Promotion &, 152 & 043 &, 363 & 3,517 & , 001 &, 501 & 1,998 \\
\hline Conformity &, 090 & 034 & 207 & 2,627 &, 010 &, 859 & 1,165 \\
\hline
\end{tabular}

Source: Processed primary data, 2020.

Based on the output of multicollinearity test results using the SPSS program, it has proven that the value of Variance Inflation Factor $<10$ and the value of Tolerance $>0.10$ so that it can be stated that there is no correlation between independent variables.

\section{Heteroscedasticity Test}

Table 6 Heteroscedasticity Test Results

\begin{tabular}{|l|c|l|}
\hline \multicolumn{1}{|c|}{ Variable } & Significance & \multicolumn{1}{c|}{ Information } \\
\hline Quality of Products (X1) & 0.276 & There is no heteroscedasticity \\
\hline Promotion (X2) & 0.138 & There is no heteroscedasticity \\
\hline Conformity (X3) & 0.559 & No heteroscedasticity occurs \\
\hline
\end{tabular}

Source: Primary data processed, 2020.

Based on the output of heteroscedasticity test results, it has been obtained that the significance value of the variable product quality, promotion, and conformity is greater than 0.05 , so it is stated that heteroscedasticity does not occur.

Data Analysis Techniques Multiple Linear Regression Analysis 
Table 7 Multiple Linear Regression Test Results

\begin{tabular}{|c|c|c|c|c|c|c|}
\hline \multicolumn{7}{|c|}{ Coefficients $^{\mathrm{a}}$} \\
\hline \multirow{2}{*}{\multicolumn{2}{|c|}{ Model }} & \multicolumn{2}{|c|}{$\begin{array}{c}\text { Unstandardized } \\
\text { Coefficients }\end{array}$} & \multirow{2}{*}{$\begin{array}{c}\text { Standardized } \\
\text { Coefficients } \\
\text { Beta } \\
\end{array}$} & \multirow[t]{2}{*}{$\mathrm{t}$} & \multirow[t]{2}{*}{ Sig. } \\
\hline & & $\mathrm{B}$ & Std. Error & & & \\
\hline \multirow[t]{4}{*}{1} & (Constant) &, 094 &, 872 & &, 107 &, 915 \\
\hline & Product Quality &, 102 &, 038 &, 281 & 2,717 &, 008 \\
\hline & Promotion &, 152 &, 043 &, 363 & 3,517 &, 001 \\
\hline & Conformity &, 090 &, 034 & 207 & 2,627 &, 010 \\
\hline \multicolumn{7}{|c|}{ R: 0.698} \\
\hline \multicolumn{7}{|c|}{ Adjusted R Square: 0.472} \\
\hline
\end{tabular}

Source: Processed primary data, 2020.

Based on the output of the results of the multiple linear regression test above, a multiple linear regression equation model can be compiled as follows: $\mathrm{Y}=0.281 \mathrm{X} 1+0.363 \mathrm{X} 2+$ $0.207 \mathrm{X} 3$

The $\mathrm{R}$ value is 0.698 , so it can be concluded that if product quality, promotion and conformity increase simultaneously, consumer loyalty will also increase by 0.698 . The value of Adjusted $R$ Square is 0.472 , so it can be concluded that the effect of product quality, promotion, and conformity on consumer loyalty is $47.2 \%$. While the remaining $52.8 \%$ is explained by other independent variables not included in the regression model in this study. The regression coefficient of the product quality variable (X1) is 0.281 . The regression coefficient of the promotion variable (X2) is 0.363. The regression coefficient of the conformity variable (X3) is 0.207 .

\section{Model Feasibility Test}

Table 8 Feasibility Results

\begin{tabular}{|l|r|r|r|r|c|}
\hline \multicolumn{7}{|c|}{ ANOVA $^{\mathrm{a}}$} & Sig. \\
\hline \multicolumn{1}{|c|}{ ModelModel } & Sum of Squares & df & Mean Square & F & \multicolumn{1}{c|}{ Sig } \\
\hline Regression & 90.427 & 3, & 30.142 & 30.481 & $000^{\mathrm{b}}$ \\
\hline Residual & 94.933 & 96 & 989 & & \\
\hline Total & 185.360 & 99 & & & \\
\hline
\end{tabular}

a. Dependent Variable: Consumer Loyalty

b. Predictors: (Constant), Conformity, Promotion, Product Quality

Source: Primary data processed, 2020.

Based on the output of the feasibility of the model, obtaining a significance value of 0.000 , it is stated that the estimated regression model is feasible because the significance value is smaller than the specified value, namely 0,05 which means that the regression model which is estimated to be feasible is able to explain the effect of the independent variable on the dependent variable.

\section{HypothesisTest \\ t Test}

Table 9: Results of t test

\begin{tabular}{|l|r|r|r|r|r|}
\hline \multirow{2}{*}{ Model } & \multicolumn{2}{|c|}{$\begin{array}{c}\text { Unstandardized } \\
\text { Coefficients }\end{array}$} & $\begin{array}{c}\text { Standardized } \\
\text { Coefficients }\end{array}$ & t & Sig. \\
\cline { 2 - 5 } & \multicolumn{1}{|c|}{ B } & Std. Error & Beta & & \\
\hline (Constant) &, 094 &, 872 & &, 107 &, 915 \\
\hline Product Quality &, 102 &, 038 &, 281 & 2,717 &, 008 \\
\hline Promotion &, 152 &, 043 &, 363 & 3,517 &, 001 \\
\hline Conformity &, 090 &, 034 &, 207 & 2,627 &, 010 \\
\hline a. Dependent Variable: Consumer Loyalty
\end{tabular}

Source: Primary data processed, 2020. 
Based on the output of the test, it can be explained that the significant value for the influence of product quality variables on consumer loyalty is 0.008 . This value shows $<0.05$, so it can be stated that $\mathrm{H} 1$ is accepted, meaning that the product quality variable has a significant effect on the consumer loyalty variable. The significant value for the effect of the promotion variable on consumer loyalty is 0.001 . This value shows $<0.05$, so it can be stated that $\mathrm{H} 2$ is accepted, meaning that the promotion variable has a significant effect on the consumer loyalty variable. The significant value for the influence of the conformity variable on consumer loyalty is 0.010 . This value shows $<0.05$, so it can be stated that $\mathrm{H} 3$ is accepted, meaning that the conformity variable has a significant effect on the consumer loyalty variable.

The Effect of Product Quality on Consumer Loyalty: The results of this study indicate that product quality has a positive and significant effect on consumer loyalty. These results indicate the direction of a positive relationship, which means that the increasing product quality at the fast food restaurant " $\mathrm{X}$ ", the consumer loyalty will also increase.

The Effect of Promotion on Consumer Loyalty: The results of this study indicate that promotion is proven to have a positive and significant effect on consumer loyalty. These results indicate the direction of a positive relationship, which means that the increasing promotion given by fast food restaurants " $\mathrm{X}$ " to consumers, the consumer loyalty also increases.

The Effect of Conformity on Consumer Loyalty: The results of this study indicate that conformity has a positive and significant effect on consumer loyalty. These results indicate the direction of a positive relationship, which means that the increasing conformity to the fast food restaurant " $\mathrm{X}$ ", the consumer loyalty also increases.

\section{CONCLUSION}

Based on the results of data analysis and interpretation of the research results discussed in this study, several conclusions can be drawn, namely: Product quality has a positive and significant effect on consumer loyalty in the " $\mathrm{X}$ " fast food restaurant. Promotion has a positive and significant influence on consumer loyalty. Conformity has a positive and significant effect on consumer loyalty. Recommendations for future research, this research can be used as a reference or reference by adding other independent variables that can affect consumer loyalty such as service satisfaction and brand trust.

\section{REFERENCES}

Anggia T. R., Kawet, L., \& Ogi, I. (2015). Analisis Pengaruh Strategi Promosi, Harga, Dan Kepuasan Terhadap Loyalitas Konsumen Surat Kabar Manado Post. Jurnal EMBA Vol.3 No.2 Juni 2015, Hal. 1041-1050.

Ferdinand, A. 2002. Structural equation modeling dalam penelitian manajemen: Aplikasi model-model rumit dalam penelitian untuk tesis magister \& disertasi dotor. Badan penerbit UNDIP. Semarang.

Ghozali, Imam. 2013. Aplikasi Analisis Multivariate dengan program IBM SPSS 25. Badan Penerbit Universitas Diponegoro. Semarang.

Ghozali, Imam. 2016. Aplikasi Analisis Multivariete Dengan Program IBM SPSS 23 Edisi kedelapan. Edisi 8. Badan Penerbit Universitas Diponegoro. Semarang.

Nilawati, N. A., \& Indriani, F. (2012). Pengaruh Atribut Produk Dan Referensi Komunitas Terhadap Minat Beli Ulang Pada Kafe Kopi Miring Di Semarang. Diponegoro Journal Of Accounting Volume 1, Nomor 2, Tahun 2012, Hal 92-104.

Robert, A. Baron., \& Byrne, Donn. 2005. Psikologi Sosial. Edisi 10. Jilid 2. Penerbit Erlangga. Jakarta.

Rozi, dan Sukaris (2020). pengaruh kualitas produk, harga dan kualitas pelayanan terhadap kepuasan konsumen. Jurnal Mahasiswa Manajemen, 1(01), 33-45.

Sugiyono. 2017. Metode Penelitian Kuantitatif, Kualitatif, dan R\&D. Alfabeta. Bandung.

Sukaris, S., Hartini, s. and Mardhiyah, d. (2019) 'increasing electronic word-of-mouth activities through self-congruity and tourist values', international journal of innovation, creativity and change, 9(10), pp. 162-183. 
Tjiptono, F. dan Gregorius C. 2016. Service, Quality, dan Satisfaction. Edisi 4. Penerbit Andi. Yogyakarta.

www.topbrand-award.com (diakses tanggal 22 september 2020, pukul 10.05 wib). 